Vedecký príspevok/Scientific Article

Recenzované/ Review: 21.05. 2021

https://doi.org/10.24040/eas.2021.22.1.42-54

\title{
Barriers to internal communication in companies
}

\section{Bariéry internej komunikácie v podnikoch}

\section{Lukáš Smerek}

Abstract: The aim of the article is to identify the main barriers in internal communication in the company, which are perceived by employees of Slovak companies. The identification of the most common barriers in internal communication was carried out using a questionnaire survey among 508 employees of Slovak companies. The results were analyzed using descriptive statistics, Pearson Chi-Square test and Cramer's V. The most common barriers to internal communication include too much information, concealment of information, concerns about job loss, ridicule or mockery, personal relations between recipient and sender of information, or inappropriate selected communication channel. At the same time, there is a difference in how men and women or different age categories of employees perceive individual barriers. While women and younger employees more often perceive communicator relationships and concerns as a barrier, for men the barrier is an inappropriately chosen communication channel. Older employees more often consider a disproportionate amount of communicated information to be a barrier.

Key words: Internal communication. Company. Barriers. Employees.

JEL Classification: D83. M12.

\section{Introduction}

Communication is one of the areas in the company that managers must pay enough attention to. Its underestimating creates problems in companies that managers often do not know about because they are hidden. Many communication barriers arise in the workplace, which hinder the effective functioning and progress of the company. Communication is influenced by a large number of factors, whether from the external environment or the personal situation and characteristics of each person. That is why it is very interesting to follow the development of communication over time and in a specific environment. In the company's management system, communication acts on the one hand as a management tool and on the 
other hand as a product of management and leadership of people in the company. Its development is directly determined by the development of corporate management systems, which initiates the development and improvement of internal communication systems, communication tools, communication competencies and changes the requirements and demands for communication skills of employees (Szarková, 2018). Internal communication is a key element of corporate culture and also a tool for achieving and maintaining corporate values. The recognition of the importance of internal communication has resulted in a series of initiatives aimed at understanding and analyzing the field and advocating it as an independent domain (Verčič et al., 2012). What the situation inside the company looks like is reflected on the outside, and suppliers or clients can also feel it. The company presents itself and talks about how it can handle certain situations. Due to the processes and changes that were gradually caused by globalization, a new need arises in companies to adapt and apply new methodologies within the company in order to structure communication channels to improve quality in the processes and products, leading the company to be more competitive in the environment and obtain better performance, making full use of all its resources (Martinez, Hurtado, 2018). If the company has mastered communication internally with employees, it will externally act as a confident and organized company, which has mastered its internal side.

The aim of the article is to identify the main barriers in internal communication in the company, which are perceived by employees of Slovak companies. We identified the most common barriers in internal communication by using a questionnaire survey among 508 employees of Slovak companies. We further analyzed the results of the questionnaire survey using descriptive statistics, Pearson Chi-Square test and Cramer's V. We performed statistical testing at the level of significance $\alpha=0.05$.

\section{Internal communication in the company and barriers to its successful use}

Internal communication ensures the transfer of information between members of a company or its parts. It takes place at all levels and in the organizational units of the company. It is the transfer of information at the internal level. Internal communication is determined by the structure in the company, the conditions and rules that the company has set. Internal communication is responsible for effective communication between participants within the company. The scope of the function varies depending on the company, its management, area of operation, good management practices, or strategy (Smith, Mounter, 2008).

Internal communication involves a group of processes or tools that are responsible for the efficient flow of information and collaboration between participants within a company. Internal 
communication includes communication between top management, middle management and employees. Open and transparent communication is an excellent way to ensure that employees understand the company's mission and that everyone is in line with the company's values (Škvareninová, 2004). A good internal communication strategy ensures that everyone in the company is aware of and aligned with the main goal of the company. In this way, companies can be sure that everyone is moving in the same direction (Wright, 2009).

Successful communication in the company presupposes, in addition to understanding the rules of the communication process and its peculiarities in the company, the creation of a supportive communication atmosphere, appropriate use of communication tools and resources, respecting the principles of effective communication and improving communication skills of managers (Pružinská,Dirgová, 2009). The socially intelligent manager is empathetic and socially aware, he seeks to build the well-being of employees through regular communication, building trust, and taking them seriously and listening to them (Smutný, 2020). The level of internal corporate communication is in its own way reflected in the company's external communication with the market. According to Cowan (2014) in the field of internal communication in the company, there are two departments within which internal communication is the most important, namely public relations and human resources. In public relations, the point is that the company must choose the appropriate tools of communication and channels in order to achieve a positive impression and a good reputation in the market in order to succeed. With human resources, internal communication is important to ensure effective communication within the company, which is also taken into account by potential employees.

We consider the effective transmission of information and its correct understanding by the recipient of this information to be the basis of successful communication. It is a complex process of information exchange in which the presence of communication barriers or errors is common. These lead to unsuccessful, inefficient and poor communication. It is most important to be able to identify communication barriers, because the mutual transmission and receiving of information is an integral part of the work process of any company. These errors can be completely eliminated, partially eliminated or not eliminated at all.

Communication barriers can be differentiated into internal and external communication barriers. Internal ones are based on the internal environment, ie they are given by personal problems and obstacles of the sender and recipient of the information. External obstacles include disturbing elements in the external environment. For the purpose of removing barriers in communication, the first prerequisite is to know and admit their existence. Olexová (2007), 
Lunenburg (2010) and Harausová (2013) point to several barriers to communication that need to be addressed. Filtering information is about manipulating or distorting information. Some cases of information filtering may be intentional, but there is also unintentional filtering of information in the normal transfer of information, for example between employees, where less competent employees may filter out some important information and distort the overall report in an effort to express the amount of information. Filtering information is also possible due to the effort to keep information secret in order to gain benefits, power, importance, promotion, etc. The extent of filtering is generally a function of the number of vertical levels in the company and the culture of the organization. As the number of people in the chain involved in information transmission grows, so does the potential for information distortion. The increase in cooperation at the horizontal level and less hierarchical cooperation and communication increases the rate of elimination of this barrier. Internal communication tools such as email, chat, etc. also have a positive effect on the straightforwardness of communication between employees. To ensure the elimination of communication filter barriers, it is necessary to create a corporate culture that is based on openness and transparency, while it is beneficial when employees are not afraid to communicate openly without feelings of threat and sanctions for expressing their opinion.

Selective perception may be another barrier, which is based on people interpreting what they have seen, read or heard in their own way, according to their interests, experiences, needs and personal characteristics. An example of this is the transmission of selected information that corresponds to their ideas and opinions. Selecting of information also leads to stereotypes - for example, the manager has preconceived notions of job seekers and refuses to distinguish between individual behaviors and opinions related to, for example, gender stereotypes.

Emotions are a factor that generally influences acting opinions and everything that happens around people. The sharp and extreme emotions which hinder rational judgments are among main barriers. Previous research (Appelbaum et al., 2007; Davenport, Barrow, 2009) on communication aspects is overwhelmingly directed towards the rational component of communication. The prevalent assumption is that communication has to be open, honest, and logical in order to convince employees, and ultimately to increase the levels of identification with and commitment to the new organization, thus largely ignoring the emotional component of communication. However, employees regularly experience feelings of uncertainty and high levels of fear and anxiety mixed with anger, aggression, distrust, disappointment, frustration, and grief that may hinder the proper understanding of communication (Zagelmeyer et al., 2016).

Language can also become a barrier to communication. This understanding is not only about different foreign languages, but also barriers at the level of the same language in case 
there are differences in the understanding of words depending on age, circumstances, or knowledge of terminology, etc. Moreover, employees may misinterpret the information they are given (Chmielecki, 2015).

We can also find value differences in companies, which can occur in the case of a different ranking of values resulting from the background of people. Outdated organization of communication are barriers that can occur between generations of employees, but the problem can be the inflexibility of the organization and its obsolescence. Generational differences can be found, among other things, in attitudes to work and expectations, in the way of communication, in attitudes towards authorities, in the acceptance of new methods and practices, etc. (Čvirik, 2018). Environmental factors can also occur inside the company, which are considered to be barriers caused, for example, by too much noise in the workplace (for example in factories). Communication barriers of communicators can also lie in a low degree of so-called soft skills in communicators. Elimination is possible through the identification of the problem and the subsequent focus of development activities of employees on this area. The soft skills, which are as important as hard skills, have a lead role to play in this regard (Chmielecki, 2015).

\section{Material and research methods}

The aim of the article is to identify the main barriers in internal communication in the company, which are perceived by employees of Slovak companies. In fulfilling the goal, we look for answers to following research questions:

$\mathrm{RQ}_{1}$ : What are the most frequently identified barriers in internal communication?

$\mathrm{RQ}_{2}$ : Are there any differences in the perception of communication barriers between genders?

$\mathrm{RQ}_{3}$ : Are there any differences in the perception of communication barriers between age categories?

Table 1 Characteristics of the research sample

\begin{tabular}{|c|c|c|c|c|c|c|c|c|}
\hline \multirow{2}{*}{ Sex } & \multicolumn{4}{|c|}{ Male } & \multicolumn{4}{|c|}{ Female } \\
\hline & \multicolumn{4}{|c|}{$52.56 \%$} & \multicolumn{4}{|c|}{$47.44 \%$} \\
\hline \multirow{2}{*}{ Age } & $18-$ & & $25-34$ & \multicolumn{2}{|c|}{$35-44$} & $45-54$ & \multirow{2}{*}{\multicolumn{2}{|c|}{$\begin{array}{c}55+ \\
14.17 \%\end{array}$}} \\
\hline & 12.80 & & $21.26 \%$ & & & $24.21 \%$ & & \\
\hline \multirow{2}{*}{ Region* } & BA & TT & NR & $\mathrm{TN}$ & ZA & $\mathrm{BB}$ & $\mathrm{KE}$ & $\mathrm{PO}$ \\
\hline & $17.13 \%$ & $12.40 \%$ & $12.20 \%$ & $10.63 \%$ & $19.88 \%$ & $15.55 \%$ & $5.71 \%$ & $6.50 \%$ \\
\hline \multirow{2}{*}{ Sector } & \multicolumn{4}{|c|}{ Private } & \multicolumn{4}{|c|}{ Public } \\
\hline & \multicolumn{4}{|c|}{$75.79 \%$} & \multicolumn{4}{|c|}{$24.21 \%$} \\
\hline \multirow{2}{*}{ Employment } & \multicolumn{4}{|c|}{ Full-time } & \multicolumn{4}{|c|}{ Part-time } \\
\hline & \multicolumn{4}{|c|}{$83.07 \%$} & \multicolumn{4}{|c|}{$16.93 \%$} \\
\hline
\end{tabular}

* BA $=$ Bratislava, $\mathrm{TT}=$ Trnava, $\mathrm{NR}=$ Nitra, $\mathrm{TN}=$ Trenčín, $\mathrm{ZA}=$ Žilina, $\mathrm{BB}=$ Banská Bystrica $\mathrm{KE}=$ Košice, $\mathrm{PO}=$ Prešov

Source: Own processing, 2021. 
We identified the most common barriers in internal communication by using a questionnaire survey among employees of Slovak companies. The questionnaire was distributed using Google forms, distribution on social networks, direct contact and the use of word of mouth. Therefore, the rate of return cannot be clearly determined. The questionnaire was filled in by 508 respondents. The structure of the research sample is shown in Table 1.

We verified the representativeness of the sample using the One Sample Chi-Square Test in the SPSS software. We chose the gender and age of the respondents as the tested characteristics. We obtained data on the basic set from 2020 from the website of the Statistical Office of the Slovak Republic. We considered the basic set to be people who were employed in 2020 and were included in the public database STATdat. We performed statistical testing at the significance level $\alpha=0.05$. The results of the representativeness test are shown in Table 3 .

Table 2 Representativeness of the research sample

\begin{tabular}{|c|c|c|c|c|c|}
\hline Sex & Observed N & Expected N & Residual & Test statistics & Sex \\
\hline Male & 267 & 278.4 & -11.4 & Chi-Square & $1.030^{\mathrm{a}}$ \\
\hline Female & 241 & 229.6 & 11.4 & $\mathrm{df}$ & 1 \\
\hline Total & 508 & & & Asymp. Sig. & 0.310 \\
\hline Age & Observed N & Expected N & Residual & Test statistics & Age \\
\hline $18-24$ & 65 & 25.3 & 39.7 & Chi-Square & $67.804^{\mathrm{b}}$ \\
\hline $25-34$ & 108 & 116.8 & -8.8 & $\mathrm{df}$ & 4 \\
\hline $35-44$ & 140 & 146.5 & -6.5 & Asymp. Sig. & 0.000 \\
\hline $45-54$ & 123 & 127.3 & -4.3 & & \\
\hline $55+$ & 72 & 92.2 & -20.2 & & \\
\hline Total & 508 & & & & \\
\hline
\end{tabular}

a. 0 cells $(0.0 \%)$ have expected frequencies less than 5 . The minimum expected cell frequency is 229.6 .

b. 0 cells $(0.0 \%)$ have expected frequencies less than 5 . The minimum expected cell frequency is 25.3 .

Source: Own processing, 2021

Based on the results of the One Sample Chi-square test, we claim that the research sample is representative only by gender (asymp. sig. > 0.05). However, the sample is not representative by age (asymp. sig. < 0.05). From a deeper analysis, we found that the reason for the unrepresentativeness of the sample in terms of age is the high number of respondents under 24 years and, conversely, the low number of respondents older than 55 years. We assume that this could be due to the distribution of questionnaires using social networks. Anyway, it is a limitation of our research, and the claims we make will only apply to our research sample, not to the entire population. We further analyzed the results of the questionnaire survey using descriptive statistics, Pearson Chi-Square test and Cramer's V. We performed statistical testing at the significance level $\alpha=0.05$. 


\section{Results and discussion}

Respondents were asked to identify barriers to communication that they encounter in the workplace. Most often, they identified barriers such as too much information, concealment of information, concerns about job loss, ridicule or mockery, personal relationships between the recipient and the sender of the information, or an improperly chosen communication channel. Other identified barriers included, unclear formulation of ideas, unsuitability of the environment for communication, lack of feedback, arrogant or exalted behavior of the communicator and selective perception (Graph 1).

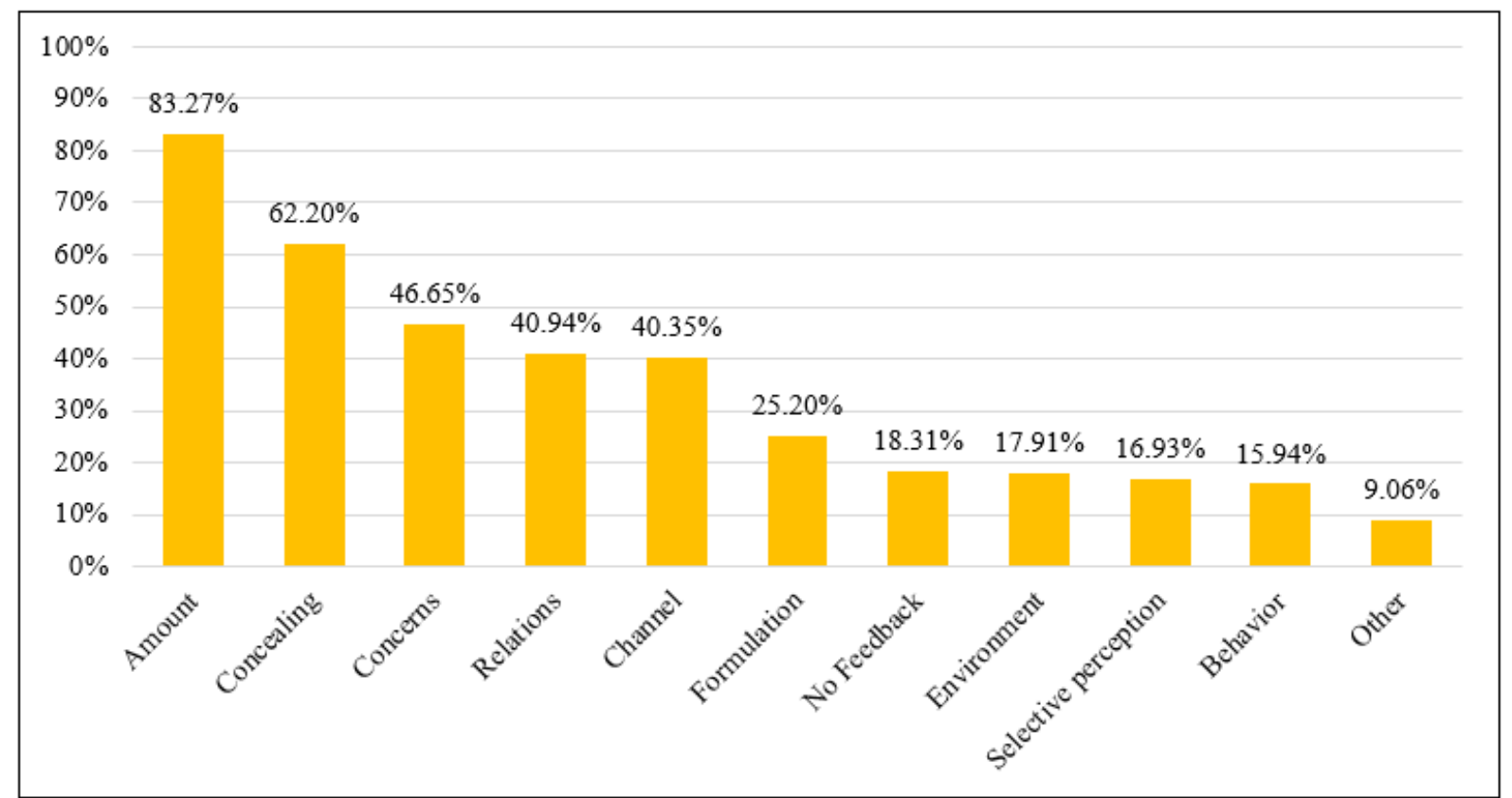

Graph 1 The most frequently identified barriers in internal communication Source: Own processing, 2021.

The two most common barriers to communication in the workplace are related to the amount of information. Respondents either feel their lack or, conversely, consider their number unbearable. The role of the manager is to communicate a sufficient amount of information to employees, but at the same time to select only those that are necessary for employees to perform their work. According to various authors (Agarwal, Gary, 2012; Conrad, 2014; Rani, 2016), the barriers that hinder successful communication includes message overload, lack of feedback, concealing the information, etc. The other two barriers could be included on the interpersonal level, where the mutual relations of communicators can be as problematic as a bad climate for the free expression of employees' own opinion. Chong (2020) came to similar conclusions, arguing that in terms of communication and success, it depends on trust between team members and team leaders. Lack of trust creates fear, suspicion and leads to team and project breakdown. 
Vetráková et al. (2015) adds that employees prefer open interpersonal communication clearing values, attitudes and aptitudes. The fifth identified barrier is of an organizational nature and is related to the selection of a suitable communication channel. According to Men (2014), the leader communication channels were found to demonstrate a positive effect on employee satisfaction. Employees tend to feel more satisfied with the organization when their managers use more face-to-face channels to communicate with them. We could argue that a different communication channel is suitable for each communication situation. But we agree that its incorrect choice can distort or completely stop communication in the workplace. Thus we responded to first research question and identified the most common barriers that employees perceive in the workplace.

As the examined variables are nominal, we used the Pearson Chi-Square test and Cramer's $\mathrm{V}$ to determine the association between gender and the perception of barriers in communication. We performed the testing at a significance level of $\alpha=0.05$. The results are shown in Table 3 .

Table 3 Association between gender and perception of barriers in internal communication

\begin{tabular}{|c|c|c|c|}
\hline & Pearson Chi-Square & Cramer's V & Asymp. sig. \\
\hline Amount of info & 2.525 & 0.070 & 0.112 \\
\hline Concealing & 1.605 & 0.056 & 0.205 \\
\hline Concerns & 314.455 & 0.787 & 0.000 \\
\hline Relations & 166.087 & 0.572 & 0.000 \\
\hline Com. channel & 221.911 & 0.661 & 0.000 \\
\hline Formulation & 0.311 & 0.025 & 0.577 \\
\hline No Feedback & 0.041 & 0.009 & 0.840 \\
\hline Environment & 0.180 & 0.019 & 0.672 \\
\hline Selective listening & 1.293 & 0.050 & 0.255 \\
\hline Behavior & 0.011 & 0.005 & 0.917 \\
\hline
\end{tabular}

Source: Own processing, 2021.

We can say at the level of significance $\alpha=0.05$, that the gender of the respondents influences the perception of relationships, concerns about losing a job, ridicule or mockery, and the choice of communication channels (asymp. sig. <0.05). For all three barriers, we identified a high association $(\mathrm{V}>0.5)$. The following graph 2 shows the proportion of men and women who perceive these barriers as problematic. 


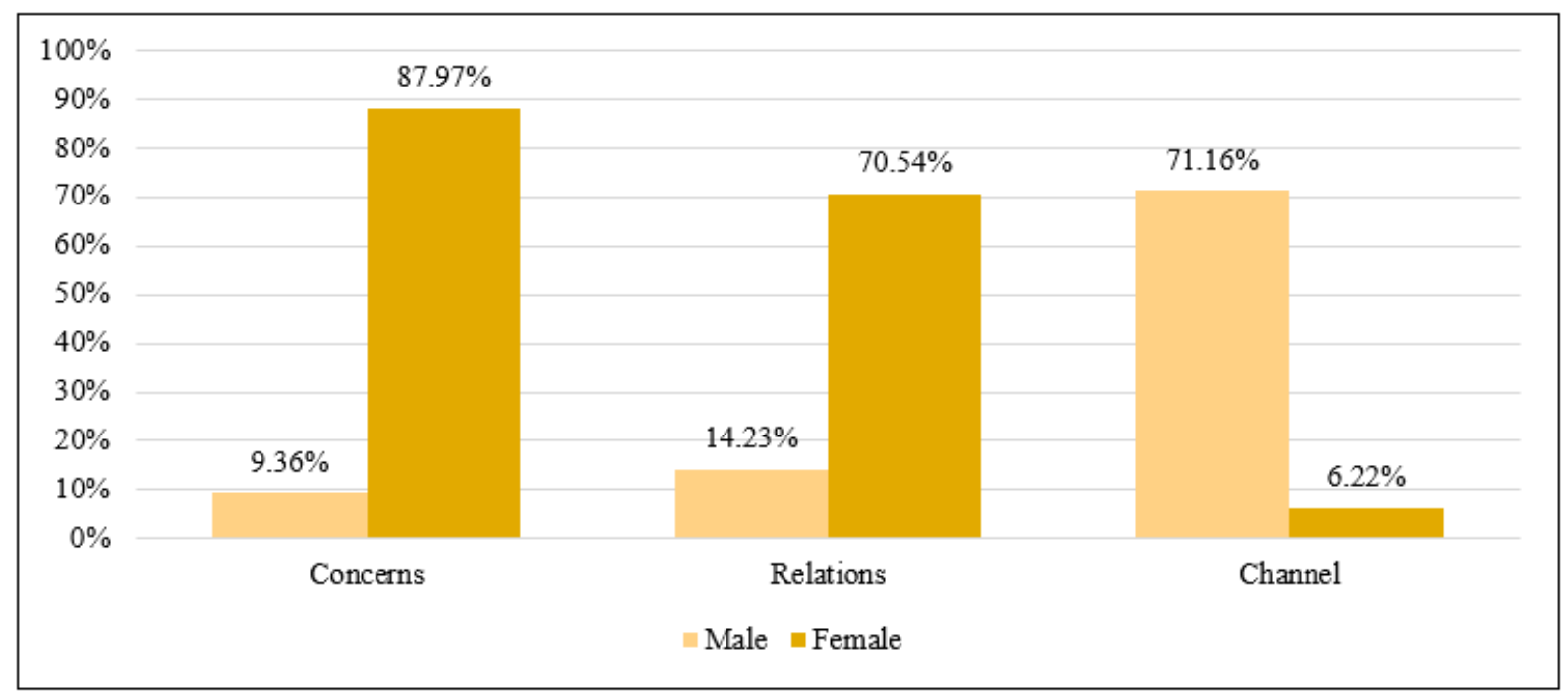

Graph 2 The rate of men and women in the perception of selected barriers Source: Own processing, 2021.

As we can see in Graph 2, 87.97\% of women addressed consider fear of job loss, ridicule or mockery as a barrier to effective internal communication, and up to $70.54 \%$ of addressed women see relationships between communicators as a barrier. In contrast, only $9.36 \%$ resp. $14.23 \%$ of addressed men perceive these barriers. For men, the right choice of communication channel is much more important, as $71.16 \%$ of them mentioned it as a barrier to internal communication compared to $6.22 \%$ of women. We answered the second research question. We argue that there are differences in the perception of three barriers between men and women.

We proceeded similarly in identifying the association between gender and the perception of barriers to internal communication. Again, we used the Pearson Chi-Square test and Cramer's V at a significance level of $\alpha=0.05$. The results are shown in Table 4 .

Table 4 Association between gender and perception of barriers in internal communication

\begin{tabular}{|c|c|c|c|}
\hline & Pearson Chi-Square & Cramer's V & Asymp. Sig. \\
\hline Amount of info & 67.110 & 0.363 & 0.000 \\
\hline Concealing & 81.498 & 0.401 & 0.000 \\
\hline Concerns & 30.320 & 0.244 & 0.000 \\
\hline Relations & 42.802 & 0.290 & 0.000 \\
\hline Com. channel & 24.971 & 0.222 & 0.000 \\
\hline Formulation & 7.345 & 0.120 & 0.119 \\
\hline No Feedback & 2.216 & 0.066 & 0.696 \\
\hline Environment & 0.540 & 0.033 & 0.969 \\
\hline Selective listening & 7.770 & 0.124 & 0.100 \\
\hline Behavior & 4.283 & 0.092 & 0.369 \\
\hline
\end{tabular}

Source: Own processing, 2021. 
At the level of significance $\alpha=0.05$, we claim that there is a moderate association $(0.3<\mathrm{V}<0.5)$ between the age of the respondents and the perception of too much or too little communicated information as barriers to effective internal communication. At the same time, there is a low but acceptable association $(0.1<\mathrm{V}<0.3)$ between responders' age and perceptions of relationships, fears of job loss, ridicule or mockery, and choice of communication channels (asymp. sig. < 0.05). The following graph 3 shows the rate of individual age categories that perceive these barriers as problematic.

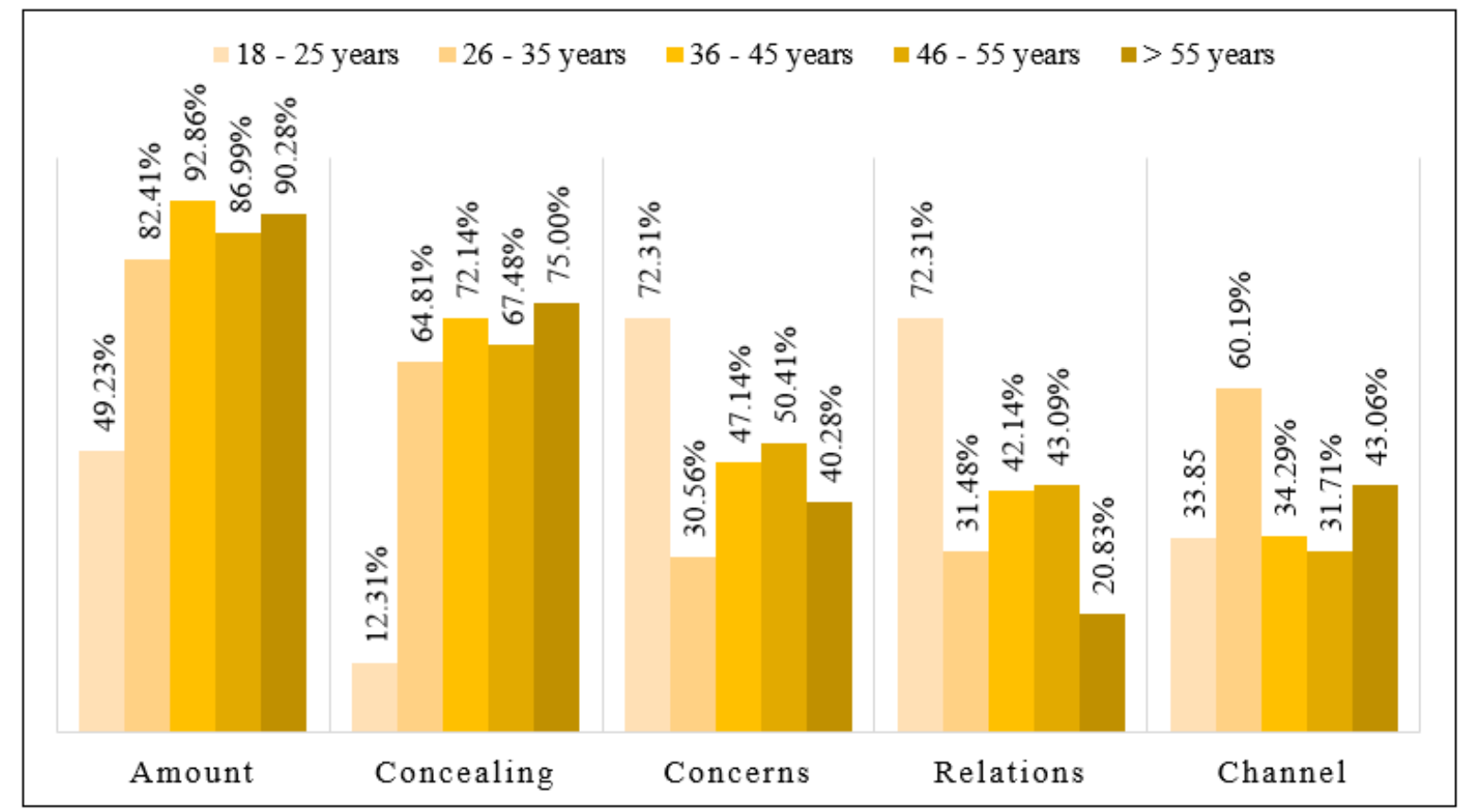

Graph 3 The rate of age groups in the perception of selected barriers Source: Own processing, 2021.

From Graph 3 we conclude that the barriers related to the amount of information are more sensitively perceived by employees older than 25 years. On the contrary, the youngest generation of employees (under the age of 25) feel more barriers in the interpersonal area. This is the answer to the third research question. We claim that there are differences in the perception of the five barriers between age categories.

\section{Conclusions}

The communication process has its principles and rules. There are guidelines for making communication effective, but there are also barriers that hinder or restrict the communication process. Among the employees of Slovak companies, we were able to identify the five most common barriers that, according to them, prevent effective internal communication in the company. Workplace relationships are extremely important. Therefore, employees must accept 
the fact that everyone is different and without mutual tolerance and respect, they will never remove this communication barrier. Negatively affected employee relationships are often caused by inappropriate problem resolution. The barrier is also the attitude and bias towards the other person with whom we communicate. This is one of the most common barriers in vertical communication, whether in everyone's work or private life. Concerns about job loss, ridicule or mockery are also a common barrier to effective communication. This situation can occur when the superior is convinced only of his own opinion and takes any objection or contradiction as an attack on his person or the position he holds. It does not matter what job position a person works in, what role he plays in society, human, decent, empathetic and polite behavior must always come first. Without it, communication between people does not work, nor does building interpersonal relationships. As for fears of ridicule or mockery, we can only say that in many cases, when subordinates do not want to express their own opinion, it is only because of their thinking that what they say will be immediately ridiculed. However, the reality is completely different, and if employees were not afraid to express their own opinion, it would significantly help to solve problems, create better relationships in the workplace and communicate more effectively. The solution is to formulate correctly what the employees want to say. Whether it is disagreement with a superior or expressing their own opinion, they must always think about what and how to say without the other party accepting it negatively. No one can force employees to agree to everything their superiors tell them, and both parties must be aware of this. These barriers in our research have been identified primarily by women and younger employees. A common problem in internal communication is the amount of information. It is not desirable if employees do not have enough information needed to perform their job duties, but on the other hand, excessive information overload makes communication confusing and slows down not only the communication itself, but also the efficiency of employees. According to our findings, older employees are more sensitive to this aspect of communication. From the point of view of communication organization, it is important to choose the right channel for a specific communication situation. The choice of a suitable communication channel is very important, and therefore it is recommended to choose the one to which the recipient is accustomed. Of course, the choice of channels also affects their effect and the stage of the communication process. Men are more sensitive to choosing a suitable channel than women. 


\section{References}

[1] Agarwal, S., \& Gary, A. (2012). The Importance of Communication within Organizations: A Research on two Hotels in Uttarakhand. Journal of Business and Management, 3(2), 4049. doi: 10.9790/487X-0324049

[2] Appelbaum, S. H., Lefrancois, F., Tonna, R., \& Shapiro, B. T. (2007). Mergers 101 (part one): training managers for communications and leadership challenges. Industrial \& Commercial Training, 39(3), 128-136. doi:10.1108/00197850710742225

[3] Conrad, D. (2014). Workplace Communication Problems: Inquiries by Employees and Applicable Solutions. Journal of Business Studies Quarterly, 5(4), 105-116.

[4] Cowan, D. (2014). Strategic Internal Communication: How to Build Employee Engagement and Performance. London, UK: Kogan Page Publishers.

[5] Davenport, J. \& Barrow, S. (2009). Employee Communication During Mergers and Acquisitions. London, UK: Routledge.

[6] Harausová, H. (2013). Komunikácia v organizácii [Communication in the organization]. Vysokoškolský učebný text. Košice, SK: Univerzita P. J. Šafárika.

[7] Chmielecki, M. (2015). Factors Influencing Effectiveness of Internal Communication. Central European Management Journal, 23(2), 24-38. doi: 10.7206/mba.ce.20843356.139

[8] Chong, C. S. (2020). Successful international communication. Training, Language and Culture, 4(1), 55-65. doi: 10.22363/2521-442X-2020-4-1-55-65

[9] Čvirik, M. (2018). Vybrané znaky generácie Y na trhu práce [Selected features of generation $\mathrm{Y}$ in the labor market]. Ekonomika a spoločnost' - Journal of Economics and Social Research, 19(2), 158-165.

[10]Lunenburg, F. C. (2010). Communication: The Process, Barriers, And Improving $\begin{array}{llll}\text { Effectiveness. } & \text { Schooling. }\end{array}$ https://www.mcgill.ca/engage/files/engage/communication_lunenburg_2010.pdf.

[11] Martinez, L. A. M. \& Hurtado, S. R. F. (2018). Internal Communication Issues in the Firms: Does It Affect the Productivity? Review of European Studies, 10(2), 1-13. doi: 10.5539/res.v10n2p1

[12]Men L. R. (2014). Strategic Internal Communication: Transformational Leadership, Communication Channels, and Employee Satisfaction. Management Communication Quarterly, 28(2), 264-284. doi:10.1177/0893318914524536 
[13] Olexová, C. (2007). Ako komunikovat' efektívne [How to communicate effectively]. Personálny a mzdový poradca podnikatel'a, 2-3/2007. Retrieved from: https://www.epi.sk/odborny-clanok/Ako-komunikovat-efektivne.htm

[14]Pružinská, V. \& Dirgová, E. (2009). Komunikácia manažéra v teórii a praxi [Manager's communication in theory and practice]. Ružomberok, SK: Verbum.

[15] Rani, U. K. (2016). Communication Barriers. Journal of English Language and Literature, 3(2), 74-76.

[16]Smith, L. \& Mounter, P. (2008). Effective Internal Communication. Kogan Page Publishers. 274 p. ISBN 978-07-4945-265-0.

[17] Smutný, F. (2020). Vplyv osobnosti manažéra na motiváciu zamestnancov [The influence of the manager 's personality on the motivation of employees]. Ekonomika a spoločnost'Journal of Economics and Social Research, 21(1), 16-24.

[18] Statistical office of the Slovak Republic. (2021). STATdat. Public database. Retrieved from: http://statdat.statistics.sk

[19] Szarková, M. (2018). Komunikácia v manažmente [Communication in management]. Praha, CZ: Wolters Kluwer ČR, a.s.

[20] Škvareninová, O. (2004). Rečová komunikácia [Speech communication]. Bratislava, SK: SPN.

[21] Verčič, T. A., Verčič, D. \& Sriramesh, K. (2012). Internal communication: Definition, parameters, and the future. Public Relations Review, 38(2), 223-230. doi: 10.1016/j.pubrev.2011.12.019

[22] Vetráková M., Seková M. \& Ďurian J. (2015). Organizational culture and human resources management in multinational companies under the conditions of intercultural environment. Economic Processes Management, 3(4), 1-16. Retrieved from: http://epm.fem.sumdu.edu.ua/download/2015_4/2015_4_8.pdf

[23] Wright, M. (2009). Gower Handbook of Internal Communication. Aldershot, UK: Gower Publishing, Ltd.

[24]Zagelmeyer, S., Sinkovics, R. R., Sinkovics, N., \& Kusstatscher, V. (2018). Exploring the link between management communication and emotions in mergers and acquisitions. Canadian Journal of Administrative Sciences, 35(1), 93-106. doi: 10.1002/cjas.1382

Author's address: Mgr. Ing. Lukáš Smerek, PhD., Faculty of Economics Matej Bel University in Banská Bystrica, Tajovského 10, 97590 Banská Bystrica, Slovakia, e-mail: lukas.smerek@umb.sk 